\author{
ARTICLES \\ Rafał Dobek (Adam Mickiewicz University in Poznań, Poznań) \\ ORCID: 0000-0001-8292-2436 \\ dobekr@amu.edu.pl

\section{LUDWIK WOŁOWSKI AND HIS CONTRIBUTION TO THE FRENCH CREDIT REVOLUTION OF THE 19TH CENTURY}

\begin{abstract}
Ludwik Wołowski was a Polish November emigrant in France. There, he gained recognition as an outstanding economist, banker and republican politician. The article focuses on the issue of mortgage loan, which is extremely important for Wolowski. It presents both the theoretical concepts of the Pole from 1834, his political activity in the years 1848-1851 aimed at changing the provisions of the mortgage law in France, and finally the moment of co-creation by Wołowski Crédit Foncier, the first modern mortgage bank in France, and the further history of the bank managed by Wołowski, in the board of which he sat until his death in 1876. In the first part, the text presents not only the criticism of the French mortgage system by Wołowski (primarily the so-called secret mortgages), but also his draft changes and the loan and mortgage model proposed by him and the companies that may grant it. In the second, it shows the parliamentary activity of Wołowski, an attempt to force through appropriate changes in the banking law and the reasons for its defeat. In the third, the most extensive, the article describes not only the very moment of establishing Crédit Foncier and the two-year period of management by Wołowski, but also the further, controversial operation of the bank until the second half of the 1870s. All this against the backdrop of the changing French Monarchy of July, the Second Republic and the Second Empire.
\end{abstract}

Keywords: Wołowski, land loan, mortgage loan, bank, Crédit Foncier, Crédit Agricole.

doi: $10.2478 /$ sho-2021-0001

\title{
INTRODUCTION
}

Ludwik Wołowski was a November immigrant associated with the Hotel Lambert. This short sentence contains most of the information on Wołowski available in Polish literature. A historian familiar with the history of Polish emigration will therefore learn about his activity alongside 
the Czartoryski family [Borejsza J., 1966; Zdrada J., 1969], about activities for the Polish school in Batignolles [Pugacewicz I.H., 2017]. A more inquisitive reader will probably find a popular academic text by Kasper Bajon from Newsweek [Bajon K., 2011], while a stubborn researcher may come across a biography by Adam Gałkowski [Gałkowski A., 2004] or two dictionary biographical notes [Gerber R., 1977: 241; Łyczywek R., 1983: 482-5]. Unfortunately, even these few and short texts contain errors and omit a significant part of Ludwik Wołowski's economic activity. It is a bit different with the French bibliography. It includes three extensive studies of Wołowski's life and thoughts, two of which, however, come from the 19th century [Roulliet A., 1880; Levasseur E., 1877; Markiewicz P., 1993] ${ }^{1}$. Finally, it should be emphasized that Wołowski is also poorly present in the historiography of Polish economic thought. Leszek Guzicki and Seweryn Żurawicki devote four pages to him in Historia polskiej myśli społeczno-ekonomicznej do roku 1914 [History of Polish socio-economic thought until 1914]² [Guzicki L., Żurawicki S., 1969: 192-5], and Wacław Stankiewicz less than half a page in his Historia myśli ekonomicznej [History of economic thought] [Stankiewicz W ., 2007: 245], but already in the work of Dariusz Grzybek [2012] or in Polska klasyczna myśl ekonomiczna na tle angielskiej i francuskiej [Polish classical economic thought against the background of English and French] edited by Urszula Zagóra-Jonsztyn [Polska klasyczna..., 2009] Wołowski does not appear. The same is true of Tadeusz Kowalik's Historia ekonomii w Polsce [History of Economics in Poland] [Kowalik T., 1992], Polska szkota historyczna w ekonomii [The Polish Historical School in Economics] by Aleksandra Lityńska [1994] or Historia powszechnej myśli ekonomicznej [The History of Common Economic Thought] (1870-1950) by Janusz Górski and Witold Sierpiński [1979]. This absence probably results from perceiving him as a representative of French economic thought rather than Polish. However, taking into account his unchanging attachment to Poland ${ }^{3}$, cooperation with Czartoryski [1960: 206-322] or references to

${ }^{1}$ It should be noted that the French works, in turn, contain errors or omissions regarding the Polish activities of Wołowski.

2 Importantly, Stankiewicz [2007] included information about Wołowski in chapter 11 "Polish economic thought in the era of partitions", thus including Wolowski among Polish economists.

${ }^{3}$ Ludwik Wołowski himself probably saw himself as a Pole and a French at the same time. In 1847 he said: I am happy and proud that France has granted me citizenship, because in this way it has allowed me to serve it, and does serving France not mean further service to Poland? “ [Wolowski L., 1847: 1-2]. 
Polish experiences in economic theory ${ }^{4}$, it seems inadequate to attribute him exclusively to French economic thought.

Therefore, it is worth reminding the Polish reader not only about Ludwik Wołowski, but also his concepts and economic achievements. Among the most important are his banking activities and related theoretical texts on the land loan. This Polish emigrant played a very important role in the reform of the French credit and mortgage system. He also contributed significantly to the establishment of Crédit Foncier, one of the most important French banks of the last 150 years. His name was thus permanently inscribed not only in the history of French economic thought, but also in the economy in general, and - through the bank - in the turbulent history of Paris and of the whole of France during the Second Empire. The aim of the text is therefore to present the concepts of a land loan, formulated by Wołowski in the 1830s and developed in the 1840s. I then intend to describe his attempts to implement these assumptions during his short-term parliamentary activity. Finally, the description of an attempt to create by, among others, Wołowski of the first large credit bank for agriculture - Crédit Foncier. It is therefore, on the one hand, about the first years of operation of the famous bank and the role played by Wołowski; and - then - about the growing importance of this institution for the entire French economy, especially during the Second Empire. On the other hand, I am going to point out the reasons for the final defeat of Wołowski: if the Pole was primarily thinking about an effective loan instrument for agriculture, then Crédit Foncier certainly failed these hopes, and over time he got involved in legally and financially highly risky operations.

The layout of the work, resulting from the indicated goals, is chronological in nature. The first chapter is devoted to the theory of land credit developed by Wołowski primarily during the July Monarchy. The second chapter deals with attempts to implement these concepts in the period of the Second Republic, when Wołowski was a deputy. The third chapter, the most extensive, describes the establishment of Crédit Foncier, the first years of the bank's operation - when Wołowski was its director - and finally its subsequent changes and transformation into one of the most important financial institutions of the Second Empire.

Such an arrangement allows for a smooth transition from banking theory to banking practice in France in the mid-twentieth century. The text also partially fills a gap in Polish historiography, as it adds to it at least

\footnotetext{
${ }^{4}$ For example in numerous articles in « Revue de législation et de jurisprudence ».
} 
an important fragment of Ludwik Wołowski's economic thought and activity. In turn, the French-speaking reader will find in them, for example, partly Polish roots of both his concepts and their implementation in the form of Crédit Foncier.

\section{THE THEORY OF THE MORTGAGE SYSTEM AND LAND LOAN}

Ludwik Franciszek Michał Rajmund Wołowski was born on August 31, 1810 in Warsaw. He first came to Paris in 1823, when he enrolled at the Collège Bourbon, and then at the prestigious Collège Henri IV. After graduating from high school in 1827, he returned to Poland. He took part in the uprising, and at the end of it, he returned to the Seine as part of a Polish diplomatic mission. He stayed here after the fall of the uprising, where he graduated in law in 1832. Two years later, after receiving French citizenship, he was entered on the list of attorneys and started working in one of the well-known law firms.

However, Wołowski was clearly more interested in problems bordering on law and economy than in legal disputes and court hearings. This is best evidenced by the fact that in 1834 he founded his own periodical with such a profile - Revue de Législation et de Jurisprudence [Legislative and Jurisprudence Review $]^{5}$.

Already in the first issue, Wołowski published a short text on a topic that was to be one of the leading themes of his academic and political activity for the next several years. It was about a land loan and the related issue of the mortgage system in France. The latter in the 1830s was governed by the Napoleonic Code of 1804. In accordance with article 2135 of the Code, mortgages for minors or spouses operated under the law. This happened regardless of whether or not an entry was made in the so-called "Mortgage office" - that is, in front of the person responsible for maintaining the counterpart of the land and mortgage register. Moreover, these

${ }^{5}$ By 1853, 49 issues of the magazine, which were commonly called "Wołowski's Review", had been published. It was written by François-André Isambert (founder of the French Society for the Abolition of Slavery), Pierre-Paul Royer-Collard (a famous intellectual and great lawyer), Odilon Barrot (leader of the parliamentary opposition), Ludwik's father Franciszek Wołowski, and Désiré Dalloz, Wołowski's employer and the great fame of the Paris bar; moreover, a whole galaxy of distinguished lawyers and councilors of state. [Wolowski L., 1835: frontispiece]. 
Figure 1. The first issue of Wołowski's magazine Revue de Législation et de Jurisprudence

Source: Bibliothèque Nationale de France [2021].

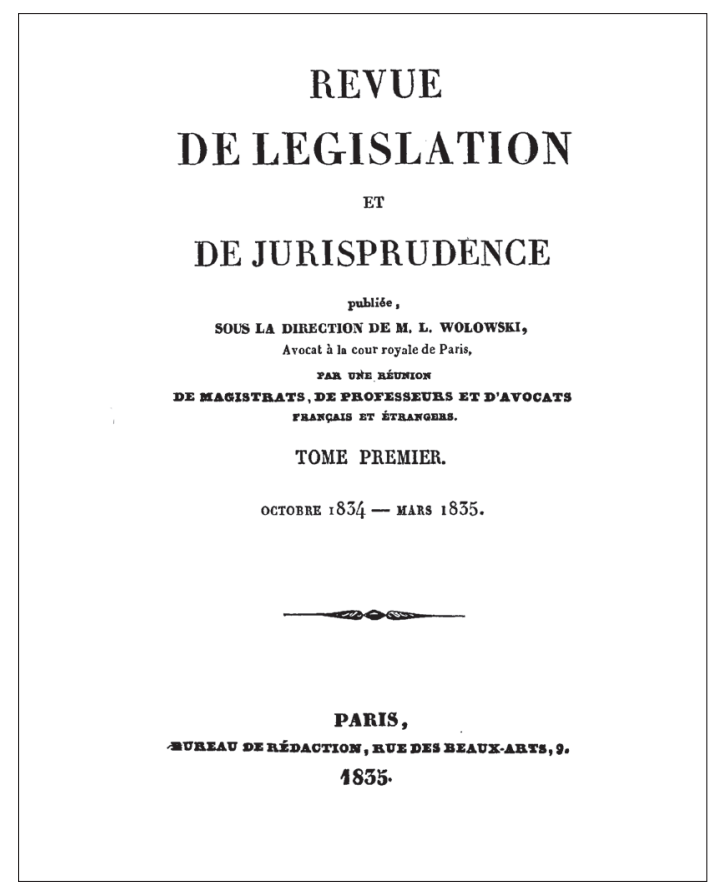

mortgages were of a general nature - that is, they encumbered all real estate of the husband or guardian, and their amount remained unspecified [Kodeks Napoleona z przypisami. Xiag trzy, 1810: 547-8]. Such a provision meant that in practice a significant part of the mortgage was hidden, which in turn had a negative impact on the real estate turnover and the related loan. In the mentioned article, Wołowski wrote unequivocally that the key issue was full disclosure for the buyer and the lender of all records related to the ownership of the real estate and related burdens [Wolowski L., 1835]. This subject was developed by the Pole in another text from the "Revue de législation". Starting from the general statement that the state should give the French economy a clear modernization impulse, he further concluded that one of the key elements of this impulse should be a change in the mortgage law. The point was, repeated Wołowski, that the lender should know: 1 . the nature of the relationship between the borrower and the pledged property; 2 . any burdens that reduce the value of the property (e.g. various easements); 3 . the amount of liabilities already related to it - e.g. secret mortgages. It would be enough, he continued optimistically, for the land loan, so far clearly limping, to start off [Wolowski L., 1839]. He himself was to find out over time that the question was not so simple. 
At least from 1841, work was already underway to change the mortgage system in the direction set out by Wolowski. As Paweł Blajer writes, the French Ministry of Justice asked the university law departments and courts of appeal for opinions on the full disclosure of mortgages. Almost all the requested bodies supported the change [Blajer P., 2016: 113]. Yet the idea of reforming the mortgage system also met with clear resistance. Wołowski's opponents argued that the current system best protected the rights of women and children. Emphasis was placed on the bureaucratization of the system in which each property encumbrance was to be entered in the "Mortgage Office". The reluctance of some landowners to fully disclose their debts and mortgages on their properties was also significant. They also looked uncontentedly on competition which, with the help of a cheap mortgage loan, could be constituted by small city buyers or farmers. Wołowski argued with the argument concerning the protection of women and children already in his BA thesis from 1832. He wrote then that "A husband who has such a great influence on his wife will easily convince her to incur a joint and several liability with him towards a lender who might otherwise fear losses on her behalf. Then she may lose not only her property, but all her assests." [Wolowski L., 1832: 29-30]. Later, he repeated this argument several times, adding that the equal property liability of husband and wife results from the very essence of the marriage [Wolowski L., 1849: 82].

Wołowski did not limit himself to merely criticizing the French mortgage law. At the same time, he proposed the introduction of a new institution whose primary task would be to financially strengthen French agriculture and landowners, i.e. the land credit association. He also referred to the already known examples of such undertakings operating in Germany and Poland ${ }^{6}$. Wołowski devoted a separate brochure [Wolowski L., 1844] and several articles [Wolowski L., 1839; 1850a] to the issue of loan associations. At the same time, he assumed that French agriculture needed capital and credit to a degree comparable or even greater than that of industry:

${ }^{6}$ A characteristic element of the entire economic work of Ludwik Wołowski was a good knowledge of both economic theory and practical legal and economic solutions from neighboring countries: Great Britain, Belgium, the United States, German states and Poland. While references to the British or Belgian theory or practice of economics were then quite common in French thought, Wołowski was a clear exception in terms of knowledge of American, German or Polish ideas and realities. It is also worth emphasizing that he regularly used the term "Poland", different from the phrases usually used by the French, such as "Russian / Prussian / Austrian Poland", "old Poland", "former Poland", etc. 
"To set capital to meet the needs, provide them with solid and convenient investment opportunities, activate their circulation, strengthen all sources of production, reduce the price of raw materials by providing land missing instruments and lowering the interest rate - this is a complicated problem, the solution of which, in our opinion, lies, on the one hand, in the establishment of agricultural banks, and on the other, in the organization of an extensive land loan (...) "[Wolowski L., 1844: 4].

Wołowski referred to the term "agricultural banks" as those banks that were to provide working capital, for which natural persons would be the basic partner. The land loan, in turn, was supposed to be granted, not to a person, but to the land, for a much longer period. And it was the latter that the Pole devoted first and foremost attention to. Of course, Wołowski emphasized again in this context the problem of mortgage legislation. For "in order for a capitalist to obtain the guarantees he is looking for, he must know exactly the type of bond between the property and the person of the borrower; must know to what extent the borrower can dispose of the real estate, he must also know the exact value of the real estate securing the loan." [Wolowski L., 1844: 4]. But, as Wołowski emphasized, the mortgage problem was not the only problem with the French credit system. In the case of agriculture, perhaps also not the most important. Wołowski gave the amount of the French mortgage - a total of around 12 billion francs in 1843 [Wolowski L., 1844: 16]. Only that - as he pointed out - only a small part of this sum was actually invested in agriculture. Wołowski believed that it was mainly due to the excessively high interest rate on loans, usually 6-7\% [Wolowski L., 1844: 17]. With such high rates, as emphasized by the Pole, the loan not only did not pay off for the majority of farmers, but it could even become the cause of their ruin.

The Pole explained it in a simple way. In fact, in France, equity owners were reluctant to lend to farmers; and this reluctance resulted primarily from exceptionally long periods of capital repayment in agriculture. As the economist noted, each lender was primarily concerned with two elements: the safety of the invested capital with interest and the possibility of easy recovery, if necessary, of the borrowed sums. The first of these should have been secured by good mortgage legislation. In the second case, the matter seemed more difficult, because the interest of the lender was sometimes contrary to the interest of the borrower: "for the landowner, the necessity to return all capital as requested by the creditor is not only a problem, but is in stark contradiction to the very nature of the land property." [Wolowski L., 1844: 20]. In other words, the farmer was able to 


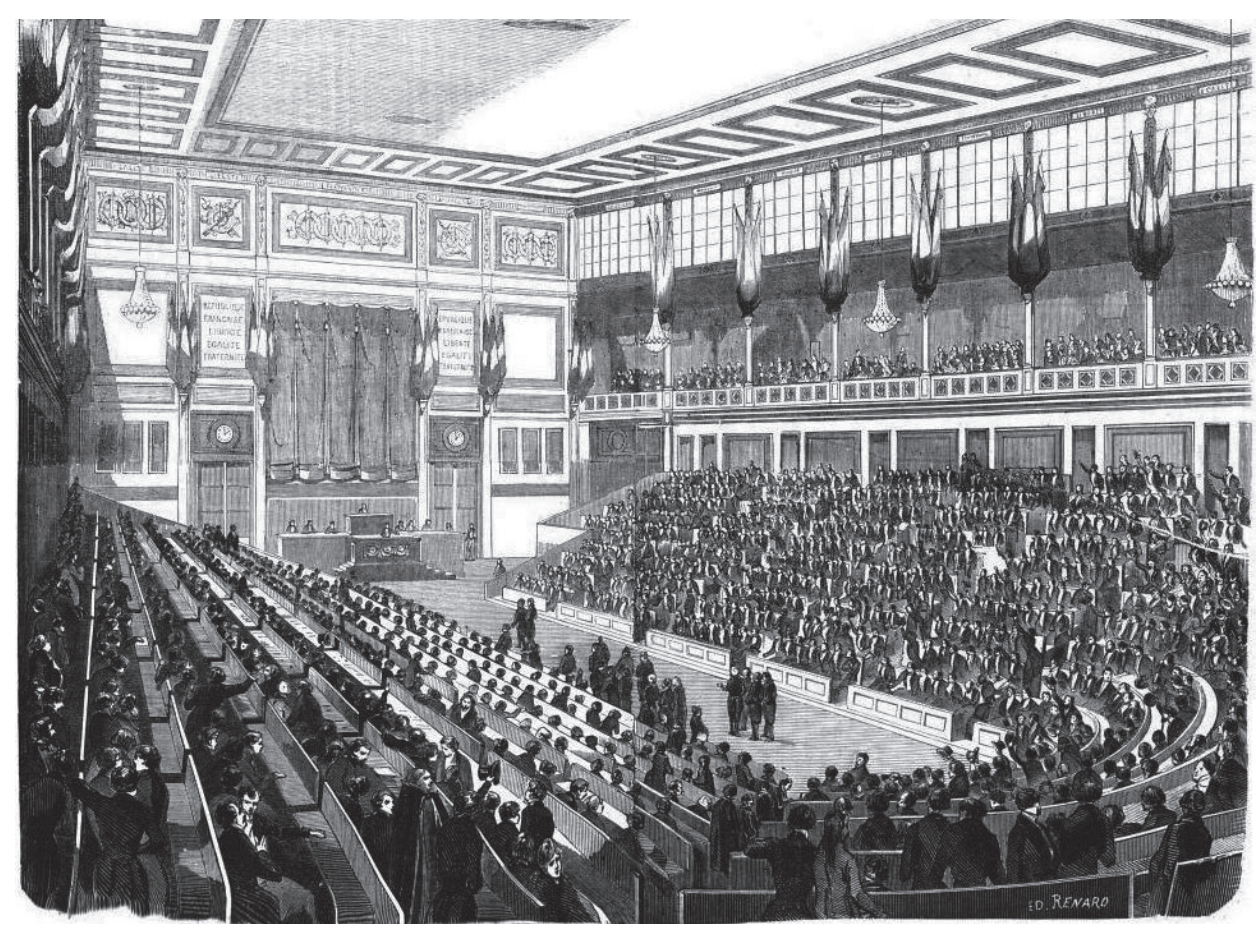

Figure 2. French National Assembly in 1848

Source: Journées illustrées de la Révolution de 1848 [1948].

pay the interest on the capital regularly, but could not quickly return the capital in full.

In order to solve the problem, Wolowski referred to an example well known to him from his youth, of the Land Credit Society ${ }^{7}$ functioning in the Kingdom of Poland. Let us remind you that the aim of the Society was to provide cheap land property loans. It granted Polish landowners loans in covered bonds up to the amount of $3 / 5$ of the value of the properties. These covered bonds brought $4 \%$ commission per year and were used to pay off mortgage loans, creditors were required to accept them at face value. However, the system guaranteed their security, as the entire Society was responsible for debt collection. Importantly, the state (which was also the largest borrower) had a significant share in it. In turn, the Society's debtors were offered a long, 28-year repayment period [Wachowicz B.,

${ }^{7}$ It seems quite likely that Wołowski came into contact with LCS through his father. Franciszek Wołowski was a well-known lawyer in Warsaw and the owner of Kaski's estate since 1823. 
1983: 62-3; Skałkowski T., 1882: 23-5]. Wołowski also referred to similar German societies, for example from Prussia, Bremen, Mecklenburg, Württemberg or Bavaria [Wolowski L., 1844: 25]. He clearly postulated, in contrast to the solutions adopted in Poland, to admit smaller property to the system (although he also emphasized that the development of land credit should prevent excessive fragmentation) [Wolowski L., 1844: 32]. He also proposed that the state treasury should play the role of a society in France, which in fact took over the vast majority of landed property.

Interestingly, Ludwik Wołowski, referring to various foreign examples, omitted the French example closest to Parisians. Well, already in 1816, Olinde Rodrigues wrote down the statutes of the Mortgage Fund ("Caisse Hypothécaire"). Even then, the fund was to be an intermediate link between the lender and the borrower. It was to be financed thanks to $4 \%$ and $5 \%$ of twenty-year bonds. The fund was to be the guarantor for mortgage loans, with the proviso that the value of the loan could not exceed half the value of the property, and the mortgage was to take precedence over any other claims and creditors. The fund started operating in 1820, it ended in 1828, mainly due to a lack of customers [Gille B., 1970: 110]. Wołowski may not have known about its existence. Perhaps he also ignored them due to the eventual failure.

\section{IN THE PARLIAMENT}

Unfortunately, Wołowski's texts initially had virtually no political response. They were sent to a small group of specialists: lawyers, economists, statisticians, and sociologists. Although his writings were probably known to several figures of the July Monarchy (his friends included, among others, Hippolyte Passy, the Minister of Trade and the two-time Minister of Finance in that period) [Markiewicz P., 1993: 55], it was not enough, however, to lead to the implementation of the idea of the Pole. So Wołowski decided to fight for it personally. In 1848 he sat on the bench of the National Assembly. He ran from the republican list of the Union Républicaine and obtained 132,333 votes in Paris [Markiewicz P., 1993: 126]. In parliament, he spoke mainly in economic debates - with one important exception mentioned below.

The elections, thanks to which Wołowski was in the parliament, were held on May 13 and 14, 1848. On June 23 of the same year, he presented his own draft law on the land loan. This rush alone testified to the impor- 
tance he attached to the issue of agricultural loans. The text of the proposal corresponded entirely to his earlier concepts. Article 1 stated that "Any owner of a property shall be able to apply to the State Treasury for the issue of a certain amount of mortgage bonds corresponding to the value of the property tax subject to 5\% capitalization." [Moniteur Universel..., 1848: 1480; 1849]. The whole was to be repaid after 23 years, but Wołowski left the debtor full freedom of early repayment.

Unfortunately, the Pole presented his project at the wrong time, or maybe in the wrong period altogether. At the wrong moment, because a little over a month earlier - on May 15 - during his speech on the Polish issue ${ }^{8}$, the meeting of the Assembly was interrupted by a crowd of Parisians, demonstrating their support for the fighting inhabitants of Wielkopolska. It quickly turned out to be a de facto coup attempt led by Louis Auguste Blanqui. Within hours, the national guard drove out most of the demonstrators and arrested their leaders. Nevertheless, many deputies from then on associated Wołowski primarily with those hours filled with uncertainty and fear. Moreover, just a few days after the Polish emigrant submitted the cited bill, another popular uprising broke out in Paris, this time against the authorities of the Second Republic. The army of General Cavaignac dealt bloody with this workers' outbreak. The insurgents, however, again drove many parliamentarians to panic. The revolutionary atmosphere was not conducive to debates on credit, so it is not particularly surprising that the Chamber did not start discussing Wołowski's proposal (and several related ones) until October 1848. However, as I mentioned, not only the moment, but the entire period was wrong. France throughout this time was in a deep economic crisis, which was to turn into stagnation which lasted until 1851 [Barjot D., 1995: 31-2]. The economic collapse was accompanied by constant political turmoil: after the June Revolution, there was a debate on the new constitution of the republic (finally adopted on November 4, 1848), the campaign before the presidential elections and the elections of December 10, decisively won by Louis Napoleon Bonaparte, and finally a long conflict between the National Assembly and the new president, which ended in the coup d'état of December 2, 1851.

${ }^{8}$ Wołowski alluded to the Greater Poland Uprising of 1848 that was taking place at that time. He called on France to show solidarity with Poland; he did not want war, but he expected a firm language from Paris towards Prussia [Moniteur Universel. Journal Officiel de la République Française, 1849: 1053). 
Figure 3. A caricature of Ludwik Wołowski as a deputy in 1848. Illustration by Honoré Daumier

Source: Daumier H. [n.d.: Wolouski].

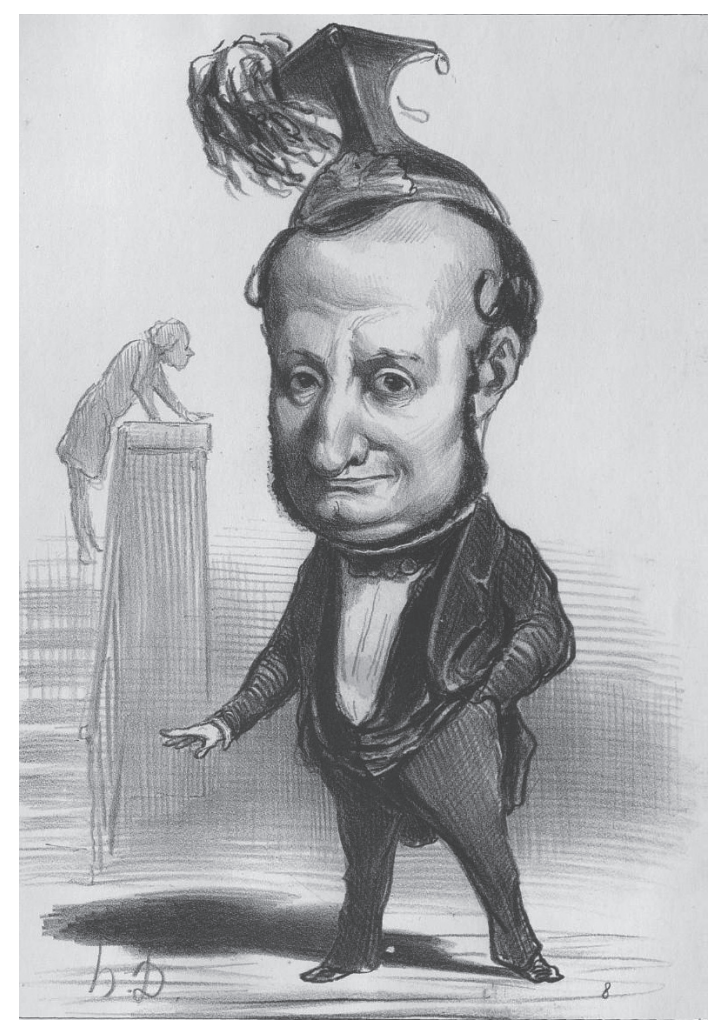

As a result, although the issue of the land loan reappeared during the parliamentary debates, it was not finally voted on. Wołowski fought for his project not only in parliament. He was also a member of the Council of Agriculture, Manufacture and Trade, operating under the Minister of Agriculture and Trade. He even managed to convince the majority of the relevant council committee in 1850, as evidenced by a report prepared by him. Compared to previous ideas, the commission's report introduced two new elements. First, the committee considered that voluntary association rather than the state would be the best solution. This position was clearly influenced by the economic crisis, as the committee was concerned that the state would not be able to guarantee sufficient security to its creditors. Secondly, the committee suggested that the society should have a guarantee fund instead of mutual responsibility. It also decided that in this case the state should participate in creating the aforementioned fund and then supervise it [Wolowski L., 1850b: 7-9]. In addition, the report repeated the already known arguments of Wołowski regarding a mortgage and easy access to cheap credit. 


\section{LUDWIK WOŁOWSKI AS BANKER. CRÉDIT FONCIER DE FRANCE}

It is possible that on the evening of December 2, 1851, Wołowski was convinced that all his efforts had finally failed. Louis Napoleon Bonaparte made a coup d'état and dissolved the National Assembly. For Wołowski, who was socially and politically connected with the Orlean party and with moderate republicans (he included himself among the latter), this meant the end of his political career. The Pole then completely withdrew to the private sphere. In the context of his later actions, it is perhaps worth noting that he did not make any attempts at active resistance at that time. He did not appear on the barricades on December $3^{9}$, nor was he among the 220 deputies gathered in the mayor's office of the 10th district who tried to remove Bonaparte from the office of president ${ }^{10}$. According to the story of Émile Levasseur, Wołowski went to the Congregation on the morning of December 2. However, the building was already surrounded by the army. The Pole was then supposed to throw his deputy ID card over the bayonets, shouting "At least it will enter" [Levasseur É., 1877: 17-8]. If it was a gesture of resistance, it was very shy. Indeed, there are many indications that on the day of the coup, a more clear support for the republic, not to mention its active defense on the barricades, simply would not pay off for Wołowski.

For on February 28, 1852, less than three months after the attack, Louis Napoleon signed a decree according to which "land loan societies could be established by presidential decree, after hearing the Council of State, aimed at providing property owners who would like to take a mortgage with the possibility of releasing through long-term repayments." [Josseau J.-B., 1872: 187]. Pursuant to subsequent articles of the decree, the debtor could take out a mortgage in this way only after paying off all previous creditors (the real estate could therefore not be encumbered with any other mortgage, including secret mortgage, Art. 6). The value of the loan could not exceed half of the value of the encumbered property (Art. 7). The debtor was to repay the loan in annual installments, and he could also pay off the loan in full at any time (Art. 10). The installments were to include

${ }^{9}$ As Philippe Vigier writes, only about twenty deputies from the left decided to take this step [Vigier Ph., 1995].

10 They were mainly representatives of the parliamentary right. Their names are mentioned by Joseph Décembre and Edmond Alonier [Alonier E., Décembre J., 1868: 140-1]. 
interest not exceeding 5\%, amortization (not less than $1 \%$ and not more than $2 \%$ of the debt value, Art. 11) and bank costs. The bank had the right to issue debentures and mortgage bonds (Art. 13) - their value, however, could not exceed the value of the loan (Art. 14) [Josseau J.-B., 1872: 188-9]. One month after the above-mentioned decree, Bonaparte signed another one, establishing the first land bank. Its share capital was 25 million francs, divided into 50,000 five hundred franc shares. To start operating, the bank had to obtain subscriptions for the first 20,000 shares; the activities of the institution itself were to be based on the provisions of the decree of February 28. The area of this activity was to include 7 departments under the Paris Court of Appeal: Seine, Seine-et-Oise, Seine-et-Marne, Eureet-Loir, Aube, Marne and Yonne [Josseau J.-B., 1872: 212-4]. Interestingly, the name of the bank - Banque foncière de Paris ("Paris Land Bank") was mentioned only in the title of the decree, in the text it was only referred to as "the company". One of the founders of the bank, and then its first director, was Ludwik Wołowski.

There is no doubt that the talks on the establishment of a new land bank had to take place before December 2, 1851. This is evidenced by the pace of preparation and signing of the decrees of February 28 and March 28,1852 . It is also obvious that they were connected from the very beginning. Louis Napoleon Bonaparte, when signing the first of them, must have already known about the preparations for the establishment of the Banque foncière de Paris.

This explains in part Wołowski's calm, almost indifferent attitude on the day of the coup - any attempt at real resistance would most likely cost him the loss of the position of the director of the future bank, thus losing not only significant income, but also informal connections and influence, important even in the Polish context.

This list of connections and influences is well illustrated by the names of the founders and first shareholders of Banque foncière. Despite its length, it is worth quoting it in its entirety (after the decree of March 28 ) - it shows well not only the network of Wołowski's connections, but also the specificity of the financial world of the Second Empire. So they were: “P. Bartholony, banker; Mr. Drouyn de l'Huys, Vice-President of the Senate; Mr. Léon Faucher, former minister; count Ksawery Branicki, land owner; Prince Sapieha, landowner; Mr. Adolphe d'Eichthal, member of the Paris City Commission; Mr. Benoist d'Azy, former representative of the people; count de Mouchy, MP; count Hervé de Kergorlay, MP; Mr. Emile Pereire, Saint-Germain Railway Director; Mr. Thibaut, for- 
mer notary; Baron Charles de Ladoucette, Senator; count de Gasparin, former French parish, former minister; gentlemen Paccard, Dufour and Co., bankers; Mr. de Waru; count de Plancy, MP; Mr. Achille Fould, senator; Mr. Hippolyte Passy, former minister; Mr. Darblay Senior, Former MP; Mr. Darblay Junior Member of Parliament; Léopold Javal, banker; count de Chappedelaine, landowner; Mr. Hély d'Oissel, former State Councilor; Mr. Cotelle, former MP; Mr. Léonce de Lavergne, professor at the Agronomic Institute of Versailles; count de Brosses, landowner; general, count Dunin-Wąsowicz; Mr. Charles Rhoné, landowner; Mr. de Renneville, former MP; Mr. Adolphe Dailly, Postmaster in Paris; Mr. Wołowski, a former representative of the people." [Josseau J.-B., 1872: 211-2]. As noted by Jean-Pierre Allinne, the author of the most extensive history of the bank, the list includes representatives of very different, sometimes seemingly distant, political and economic circles. So they were Bonapartists (including Edouard Drouyn de Lhuys, Philippe de Mouchy, Aymé-Stanislas Darblay, Kergorlay, Renneville), people associated with Orleanism (Passy, Adrien-Etienne de Gasparin, Wołowski himself), legitimists (Denis Benoist d'Azy) and a large group of figures such as Achille Fould, who functioned excellently both during the July Monarchy and the Second Empire. The group of first shareholders also included the most prominent representatives of the world of finance and industry. First of all bankers, among whom the name of Emile Pereire stood out. However, it is also worth noting another: François Bartholony. While the most powerful of all, Rothschild, was missing, Paccard was associated with him. Pereire, Bartholony, Mouchy and Benoist d'Azy were at the same time a group of industrial tycoons; in the bank they met the owners of enormous estates such as Darblay (father Amé and son Paul), Kergorlay or Drouyn de Lhuys [Allinne J.P., 1984: 30-31]. Finally, a separate group among the founders were Poles: apart from Wołowski, Branicki, Eustachy Kajetan Sapieha, and Stanisław Dunin-Wąsowicz.

Wołowski himself, for at least several reasons, seemed to be the right person to connect such diverse circles. Although he was politically associated with the Second Republic and earlier with the July Monarchy, he also had connections among Bonapartists. He was a friend of Napoleon Józef Ney (the marshal's son), who probably introduced him to this circle. He also knew Charles de Morna, half-brother of Napoleon III and with time one of the most powerful figures of the empire [Markiewicz P., 1993: 45].

While visiting Ney, Wołowski in turn had to meet his wife Albine Étiennette Laffitte, daughter of one of the greatest Parisian bankers in the 
first half of the 19th century. Through her, he probably also came into contact with representatives of the financial world. The latter could also be known for his political and economic activity, e.g. for supporting the principles of the free market and for his activities within the framework of the French Free Trade Association established in 1846. If nationality did not necessarily favor Wołowski, it certainly did not interfere either: in all these bodies the Polish cause enjoyed greater or lesser sympathy. Finally, the opinion of an expert on the subject of mortgage loan, which was enjoyed by the Pole, was important.

Therefore, Ludwik Wołowski had significant advantages which allowed him to take the position of the bank director. As it turned out quite quickly, however, they were not enough to maintain it. The economist remained at the head of the bank's management board for two years. At that time, however, the first key change in its activities had already taken place.

Quite quickly, the required minimum capital was collected and - as is clear from the Wołowski circular to notaries - Banque foncière de Paris began its operation at the turn of September and October 1852 [Josseau J.-B., 1872: 304]. Before he could develop it for good, he changed... the name and geographic scope.

This change resulted from an agreement signed between the bank and the Minister of the Interior, Victor de Persigny. Persigny was one of the oldest and closest associates of Napoleon III. He was also a supporter of banking reform and the provision of loans to agriculture ${ }^{11}$. It resulted from both economic and political calculations: the emerging Second Empire wanted the clear support of the French countryside - in the midnineteenth century, its inhabitants constituted 75\% of the French [Barjot D. et al. 1995: 78]. Hence the concept of extending the geographic scope of the bank's operations to cover the entire territory of France. It was not with-

11 This is evidenced by his circular to the prefects, sent on April 15, 1852. Persigny wrote in it: "For a long time, agriculture has rightly complained about the expensive amount of money lent to it, the size of the borrowing costs and the difficulties associated with the need to quickly repay capital, which, when used to improve the quality of the land, gradually pays off in agriculture by increasing yields over many years. . As a result, the debt increases day by day, and land ownership not only cannot count on debt relief or the improvement of management conditions, but eventually falls under the overwhelming burden. This situation could not escape the attention of the President of the Republic. Convinced of the need for a quick and effective remedy, as requested by the official agricultural interests, he said it was time to take urgent action to provide land ownership proper to its nature and credit needs." [Josseau J.-B., 1872: 214]. 


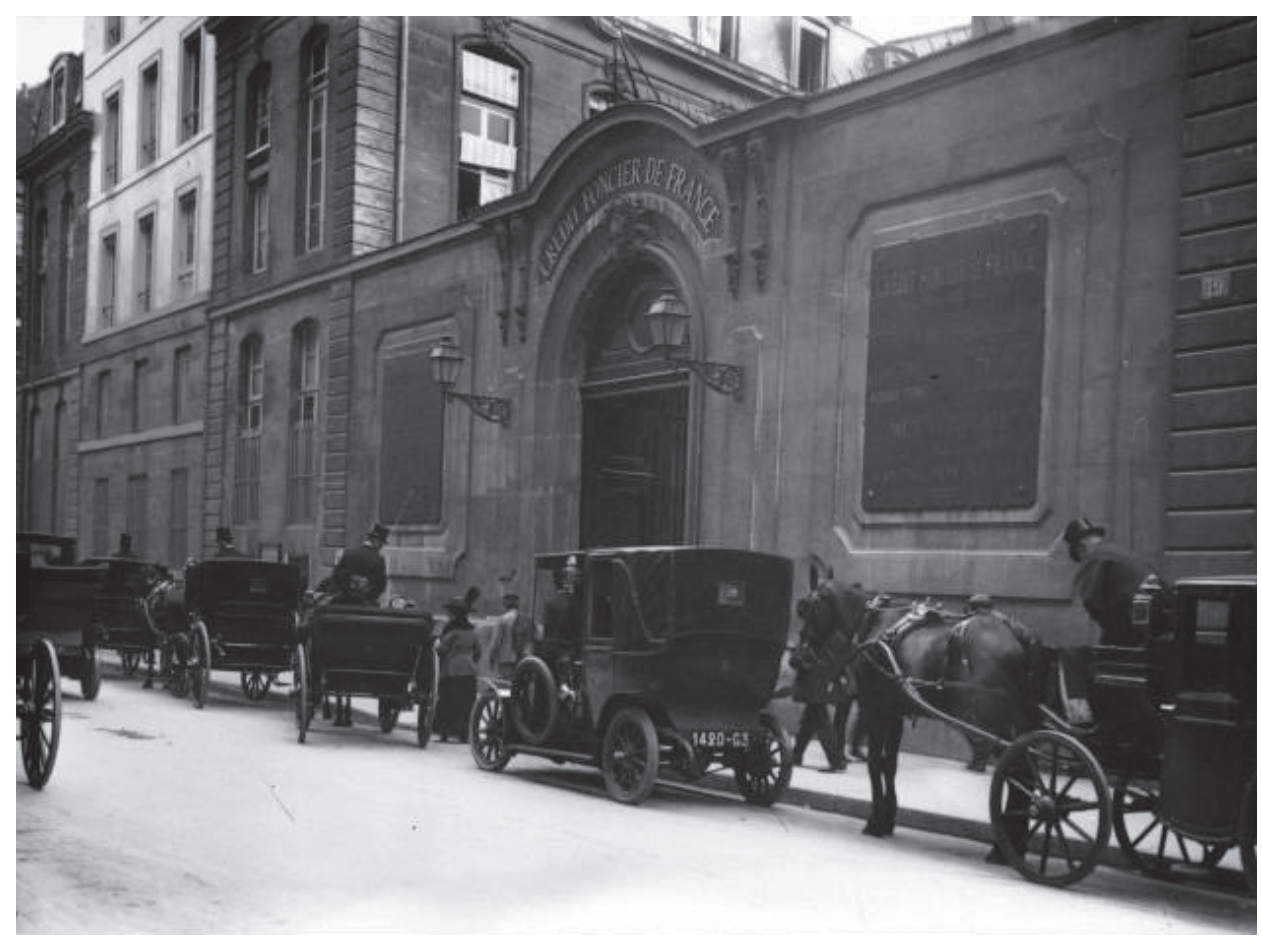

Figure 4. The headquarters of Crédit Foncier in Paris, rue des Capucines, 1913. Photo. Agence Rol.

Source: Bibliothèque Nationale de France [2021].

out significance that Wołowski's bank was by far the largest institution of this type, practically devoid of competition ${ }^{12}$. The empire, by granting permits to operate throughout the country, in fact tried to provide credit to farmers and landowners operating far away in the provinces. This, in turn, was associated with the need to change the name of the institution, which ceased to be "Parisian" and became a nationwide one. In order to avoid misunderstandings and conflicts with the then only nationwide bank Banque de France - the name "Crédit Foncier", which is still functioning today, was adopted. Persigny also introduced provisions to the contract to link the bank more closely with agriculture: $\mathrm{CF}$ undertook to grant

12 As Aline Raimbault and Henri Heugas-Darraspen write in the years 1852-1853, a total of a dozen or so institutions were established based on the decree of February 28. However, only a few in practice took up this activity - incl. in Marseille and Nevers. However, all of them were much weaker than the Paris original and were absorbed by it over time. [Heugas-Darraspen H., Raimbault A., 1994: 35]. 
loans in the provinces in the amount of at least 200 million francs within 4 years, the contract also specified their maximum interest rate $(5 \%)$. In return, the Empire allowed the bank to raise its share capital to 60 million and pledged a subsidy of 10 million francs [Josseau J.-B., 1872: 231-2]. This contract was then confirmed by imperial decree of December 10, 1852.

Frankly speaking, Wołowski did not have much choice when signing the contract. The sale of stocks and bank bonds, intended to finance the bank's operations in the long run, did not go as hoped. As a result, the bank itself artificially maintained their price on the Paris stock exchange, which ultimately resulted in a loss of 3 million francs at the end of 1853 [Allinne J.P., 1984: 33]. These problems seem to have resulted from two factors. First, Crédit Foncier still lacked a permanent anchorage outside Paris. Although the bank had 29 non-Paris branches at the end of '53, it was still not enough, moreover, they were not efficient. Second (and more importantly), the tight lending conditions imposed by the state, including the $5 \%$ interest rate cap and the 1-2\% amortization band, made Crédit ill-adapted to changing market conditions. The agreement with Persigny and the decree of December 10 slightly improved the bank's condition, but did not fundamentally change the way it operated. The actual correction came in 1854 . It also closed the bank's construction period. And the rule of Wolowski.

The initiative again came from the state. By decree of July 6, 1854, Napoleon III granted a new statute to Crédit Foncier. Pursuant to its Article 7, it eliminated the earlier restrictions on interest rates on loans. Article 8 , in turn, allowed for short-term mortgage loans without amortization, based on the share capital of the bank. The emperor also completely reorganized the bank's management. Since then, it has been headed by the president (gouverneur) and two vice-presidents. The president presided over the management board of the bank, conducted general meetings of shareholders, all bank documents had to be signed by him [Josseau J.-B., 1872: 256-7].

The change was partly due to economic and financial reasons. The new statute was modeled on the statute of the Banque de France, a French central bank enjoying enormous prestige. This raised Crédit Foncier's position and strengthened customer confidence in the bank. Moreover, the abolition of interest rate restrictions increased the attractiveness of the bank's loans. It also opened up the possibility of using mortgage loans in cities to a greater extent. Moreover, it was characteristic that the words "agriculture" or "land ownership" did not appear once in the text of 6 July. Meanwhile, a year earlier, Georges Haussmann became the prefect of Paris, and the 


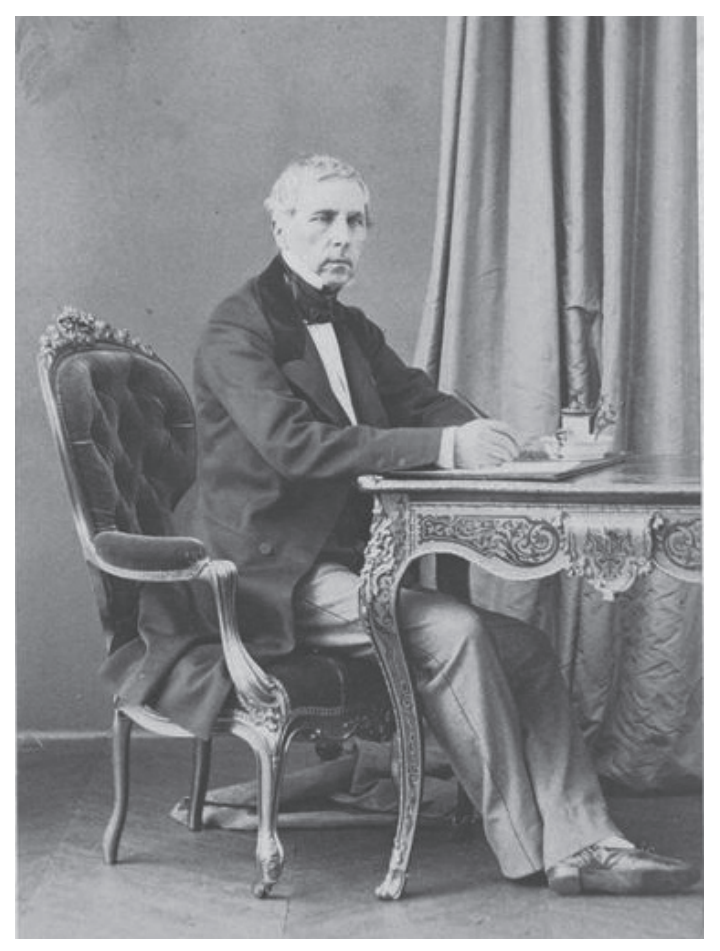

Figure 5. Charles de Germiny, photo: Alexandre Ken, date unknown

Source: Musée d'Orsay.

great reconstruction of Paris began, financed mainly by loans. It seems that even then people such as Haussmann, Persigny and Jean-Martial Bineau (finance minister) perceived Crédit Foncier as one of the tools enabling them to raise funds for the gigantic transformation of the capital.

However, the French authorities also pursued a certain political goal. The bank, which in the future was to carry out tasks extremely important also for Napoleon III, had to be subject to stricter state supervision. Previously, in practice, this supervision was illusory. Hence, probably ${ }^{13}$ the change in the head of the bank: the first president (in accordance with the new statute) was Count Charles de Germina. This former (shortlived) minister of finance from 1851, clearly declaring his attachment to the Empire, was from the authorities' point of view a much safer partner than Wołowski - too closely related to the July Monarchy and the Second Republic by family and society circle. Patrice Markiewicz quotes an anec-

13 One of Wołowski's 19th-century French biographers suggests that the change was not political, but personal. However, he does not explain them, pretending to respect Wołowski's privacy [Roulliet A., 1880: 214]. 
Figure 6. Louis Frémy, photo: Atelier Nadar, 1870

Source: Bibliothèque Nationale de France [2021].

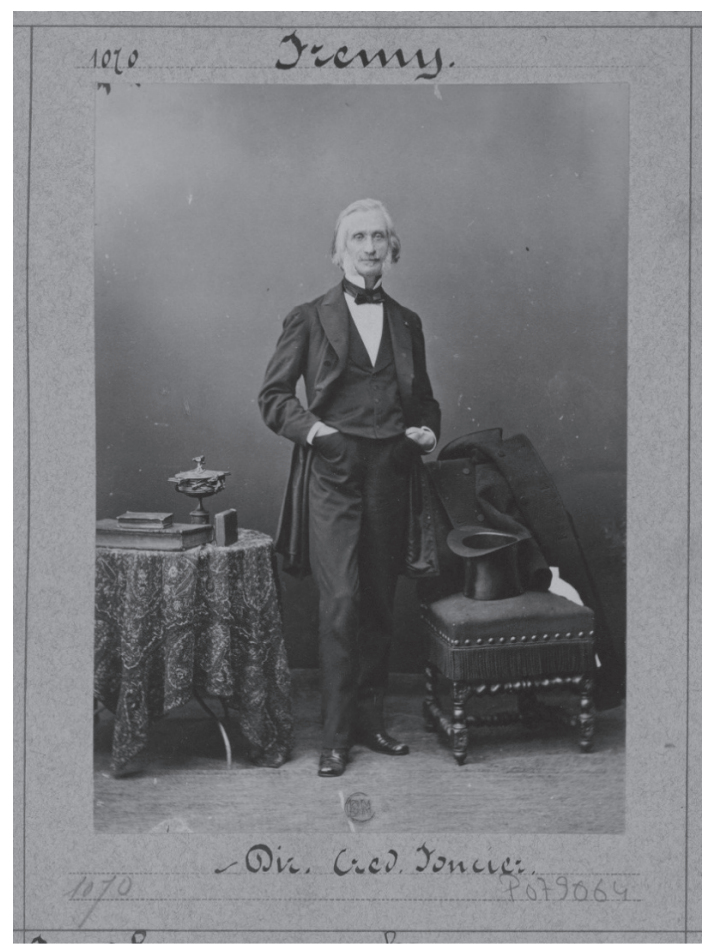

dote according to which Germiny was to offer the Pole a generous salary when he was leaving; the latter, however, was to reply that he did not want money because "the Crédit Foncier organization made it possible for me to pay off my debt to my adopted country, and now I would only like to serve it with you." [Markiewicz P., 1993: 336]. Unfortunately, Markiewicz does not provide the source of these words, which seem doubtful - probably to understand them as a proposal for further cooperation. The fact is that Wołowski remained a board member of Crédit Foncier - which otherwise, not only financially, meant more than any award. However, this does not change the fact that his influence on the bank's further activities was already relatively small: the new management board, as in the previous one, was dominated by representatives of the big financiers - including Germiny, a member of the board of the powerful railway company Compagnie des chemins de fer du Nord [Allinne JP, 1984: 35].

The personnel changes at Crédit Foncier did not end in 1854. Germiny only held the position of president for three years, moving in 1857 to the much more significant and prestigious position of president of the Banque de France. Louis Frémy then took his place. He was previously director of 
the office of Leon Faucher, the minister of internal affairs during the republic. According to Dictionary of French Parliamentarians from 1891 [Bourloton B., Cougny G., Robert A., 1891: 65], he was also a friend of the minister. So it seems more than likely that he also met Wołowski at that time: Faucher was the husband of Aleksandra Wołowska, Ludwik's sister. Given this assumption, it is not surprising that Wołowski retained his position on the board until his death in 1876. What's more, his son-in-law Louis Passy also found a job at the bank.

Another significant figure to appear in Crédit Foncier was Vice President Jean-Marie de Soubeyran. Previously, a clerk and director of the cabinet at the Ministry of State had strong ties to Fould ${ }^{14}$. The appointment of previously poorly known officials could have meant the state's desire for greater subordination of the bank to itself. In practice, however, little has changed in the way the bank was managed. The key decisions were sovereignly made by Frémy and Soubeyran. And they led the bank to flourish, but at the same time led to enormous controversy and criticism.

So Wołowski personally suffered a moderate defeat. However, it had a double character, not only personal but also institutional. Crédit Foncier never lived up to the hopes of the Pole and never became an agricultural bank, neither during his rule, nor later. From the beginning, the vast majority of the loan went to the cities. In the first years, the beneficiaries of its activities were mainly construction entrepreneurs and owners of municipal properties, and 70\% of loans went to Paris alone [Heugas-Darraspen H., Raimbault A., 1994: 39]. This trend was supposed to continue. As André Gueslin writes, by 1913 the bank had borrowed a total of 5.28 billion francs for municipal property, while the amount of loans granted to the village at the same time was only 1.37 billion [Gueslin A., 1978: 105]. Moreover, these data do not fully reflect the reality: a significant part of the money borrowed outside the city as a pledge of land did not later go to agriculture. The reasons for this state of affairs were numerous, largely independent of the bank. French farmers traditionally distrusted bankers, mostly from a foreign city. In many cases, technical and organizational considerations played a role: distance from a bank branch/representative,

14 Allinne even suggests that Soubeyran was the illegitimate son of Fould [Allinne J.P., 1984: 63]. He also points out that his extremely rapid promotions at the Ministry of Finance, the Ministry of State and, finally, at the bank took place at times in which Fould was the minister responsible. 
the need to pay a lawyer or notary. Legal restrictions were also important: Crédit Foncier required unequivocal confirmation of ownership, which in the nineteenth-century conditions was sometimes troublesome or impossible. Added to this were the requirements of the bank itself. First of all, the amount of all credit fees was too high, usually exceeding the annual land income, still relatively small in France. The repayment of the mortgage also assumed many years of regularity, which was lacking in agriculture for natural reasons. Unfortunately, as long as the bank could count on great profits from city loans, it was impossible to change this state of affairs.

In this situation, probably a small consolation for Wołowski was the change in the law, which took place in 1855, among others after many years of his efforts. The new act abolished secret mortgages and introduced almost complete transparency in property ownership records [Troplong R.T., 1856: 1-2].

Meanwhile, Crédit Foncier largely credited the reconstruction of Paris (and to a much lesser extent Marseilles too). Initially, these operations were completely legal. The bank undertook, inter alia, already during the administration of Germiny, cooperation with the Société Immobilière of the Pereire brothers, a company erecting some of the new buildings. Over time, the company's debt in Crédit Foncier reached 70 million francs. The bank financed not only the Pereire brothers, but also other entrepreneurs, contributing to the reconstruction of, among others, Rivoli street, Champs-Élysées and Malesherbes boulevards or the squares of the Opera, Vendôme and la Madeleine [Heugas-Darraspen H., Raimbault A., 1994: 63]. However, a key role was played by Crédit Foncier in the second stage of the transformation of the city on the Seine after 1860.

Haussmann's major city operations were consuming ever greater sums. By 1865, the prefect had taken legally - that is, with the consent of the Legislative Body - a total loan of 460 million francs, mainly in the form of bonds purchased by individuals [Girad L., 1981: 345]. However, this sum was not enough to cover the cost of further work, and for political reasons, the prefect could no longer count on the favor of the deputies and another loan. However, he found a way to bypass parliamentary control. The mechanism was relatively simple: the city commissioned construction contractors to demolish a specific area after proper expropriation. It undertook to pay the costs within six years. Although entrepreneurs could count on profits from the resale of rebuilt or at least demolished land, they had to pay the city a deposit corresponding to the expected payments for 


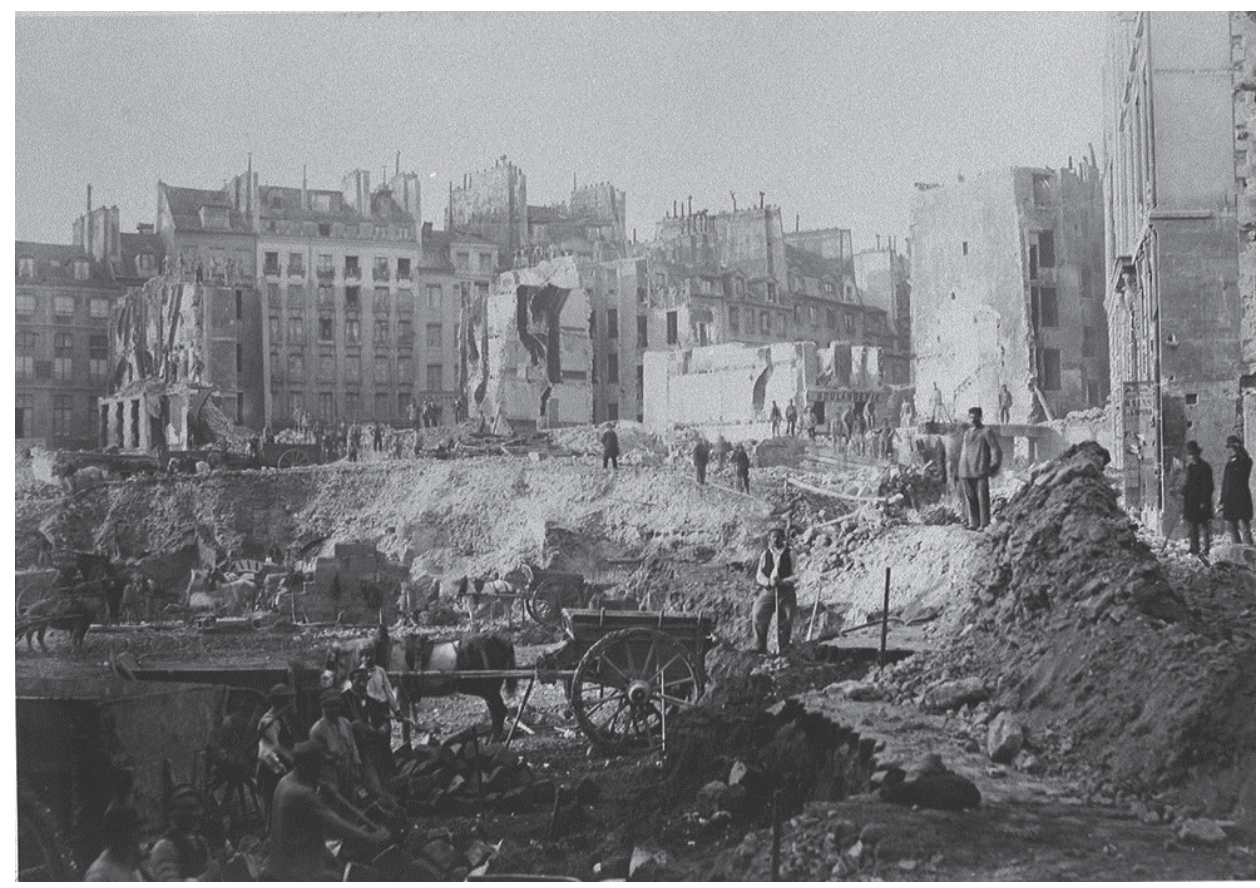

Figure 7. Works during the construction of avenue de l'Opéra, at Butte du Moulin and rue Saint-Roch. Photo Charles Marville, 1862

Source: Bibliothèque Nationale de France [2021].

expropriation. To do so, they received vouchers ("bons de délégation") from the city, corresponding to all the costs, which they then transferred to the banks. Theoretically, the city should have repaid the vouchers after the aforementioned six years [Girard L., 1981: 346]. Crédit Foncier played a key role in this process: although many banks participated in it, it was the one established by Wołowski that definitely dominated. By January 1 , 1868 , the bank thus granted the city a loan of 460 million francs, of which 398 million were still to be repaid [Marchand B., 2011: 8].

Moreover, this was not the only form of Crédit Foncier's involvement in financing Haussmann. In 1860, with the consent of the authorities, a kind of "daughter company" of Crédit Foncier - Crédit Agricole ${ }^{15}$. was established. The share capital - 20 million francs - came from a loan from

15 The then Crédit Agricole should not be confused with the bank of the same name that still exists today. The former went bankrupt in 1876, while the history of the latter begins only in 1894. 
Crédit Foncier. Crédit Agricole, formally completely independent, was, however, connected with the parent company with a similar statute and with exactly the same personnel composition of the authorities. So also Ludwik Wołowski sat in them.

As the name suggests ("agricultural credit"), it was once again "to provide capital and credit to agriculture and related industries" [Josseau J.-B., 1872: 96]. And it failed once again, for exactly the same reasons as before. Once again, like Crédit Foncier, Crédit Agricole was involved primarily in lending to cities, again mainly Paris. Contrary to the former, Crédit Agricole was allowed to grant short-term mortgage loans under its statute, which was again used by Parisian builders. Unfortunately, construction profits became more and more uncertain, and Crédit Agricole was making mortgages too easy and too fast, without proper collateral. So, there were loans for $3 / 4$ of the value of the pledge, 3rd or 4 th rank mortgage. Moreover, the bank got involved, largely thanks to Soubeyran and Frémy, in risky foreign investments, including in Austria, Turkey and Egypt. And it was the bankruptcy of Egypt that became the nail in its coffin, in 1876 the bankrupt Crédit Agricole was re-absorbed by Crédit Foncier [Heugas-Darraspen H., Raimbault A., 1994: 58].

The older of the two banks also had hard times, though for slightly different reasons. Its financial stability was not threatened, as the state and the emperor himself were behind Haussmann's loans anyway. It was under pressure from the authorities that at the end of 1867 an agreement was signed between the prefect and the bank, according to which the entire debt of the city was extended over sixty years, with an average annual interest rate of 5.41\% [Chaudun N., 2009: 275-6].

However, what was the best security from a financial point of view, the government guarantee for Haussmann's debts, has politically become a key problem for the bank. In the liberalizing Empire of the 1960s, opposition played an increasingly important role. It was probably only a matter of time before its representatives would carefully review Haussmann's accounts and use them to attack the prefect and, through him, the emperor himself. It finally happened in 1868, during the parliamentary discussion on the agreement. Then the Republican Jules Ferry published a brochure entitled Les comptes fantastiques $d^{\prime}$ Haussmann $^{16}$. It was a lengthy indictment

16 The title was a kind of play on words. It literally meant "Haussmann's fantastic accounts", but it could also be read as "Haussmann's tales (fairy tales)", in reference to Hoffmann's fairy tales. 


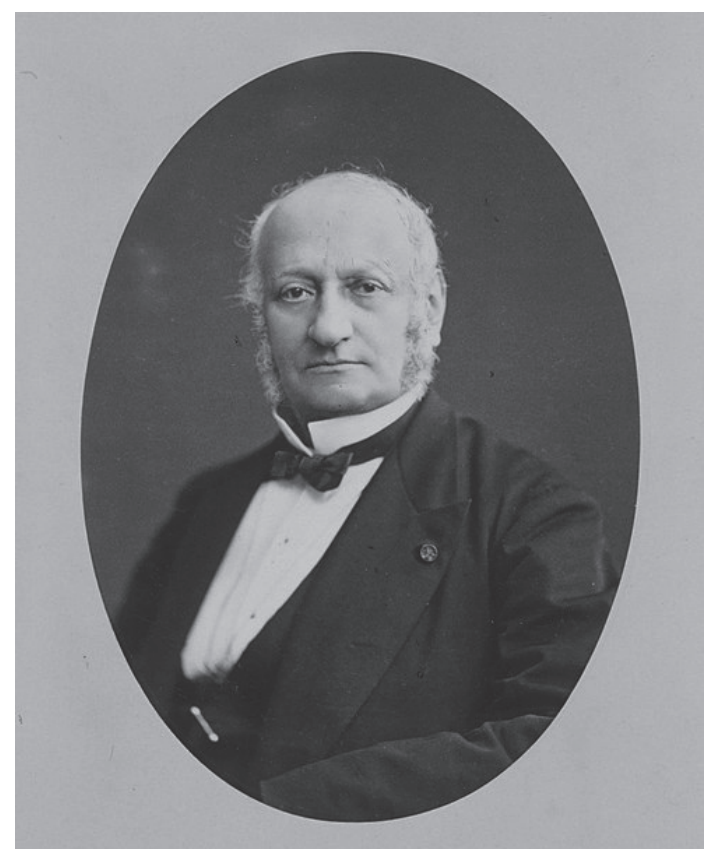

Figure 8. Ludwik Wołowski, photo by Stanisław Julian Ostroróg, January 12, 1870

Source: Polona [2021].

against the prefect of Paris and a bank whose name appeared 28 times on 93 pages. Ferry's arguments were immediately picked up by opposition deputies, so the debate took place in the pages of major newspapers and in parliament. Ludwik Wołowski also took part in the latter. It is not surprising that Wolowski defended his work. From the point of view of people such as Frémy and Soubeyran, Wołowski was at that moment an exceptionally valuable ally: as an economist with widely recognized achievements at that time, a republican who had no political ties to the empire in any way, could convince at least some of the deputies. Ferry's arguments were simple: Crédit Foncier served Haussmann as a tool for illegally financing the city, which, moreover, was extremely expensive. The first was in fact obvious and Wołowski must have been aware of it. Therefore, he bypassed it, emphasizing that Crédit Foncier was completely legal by simply buying back the city's liabilities from entrepreneurs - while the problem was that the city should not have incurred them at all, as the bank knew perfectly well [Wolowski L., 1870: 12-3]. Responding to the second objection, Wołowski claimed that the real profit of Crédit Foncier from the entire operation was 3\% [Wolowski L., 1870: 30]. Although he was clearly exaggerating here, even a historian as critical of the bank as J.-P. Allinne 
writes that the city probably paid less as a result of this operation than it would have had to choose another bank or public loan [Allinne J.P., 1984: 82].

On the occasion of Wołowski's speech before the parliamentary committee, it is worth asking a question about his responsibility for the actions of Crédit Foncier and Crédit Agricole throughout the period 1854-1876. Wołowski sat on the boards of both banks [Josseau J.-B., 1872: 314,454]. His influence on their operation could not be great - he was too insignificant figure in the world of great politics and finances of Paris. At the same time, however, he must have known about most of the major operations of both companies. Indirect proof of this is the fact that in 1873 he resigned from the board of Crédit Agricole. Patrice Markiewicz claims that it was a gesture of protest against a bank that remained "agricultural" in name only. This explanation seems doubtful because Crédit Agricole invested mainly outside agriculture already throughout the 1860s. It seems much more likely that Wołowski had already noticed the bank's financial problems and stepped down so as not to be directly related to the bankruptcy. The Pole must have known - probably from the very beginning about the dubious settlements between Crédit Foncier and Haussmann, about bad loans by Crédit Agricole, about risky investments in Turkey or Egypt. But he never protested loudly. He also did not help the opposition in any way, including many of his friends, to use these facts against the Second Empire, although he remained a moderate republican until the end of his life.

This can probably be explained in two ways. The first is obvious and concerns financial and not only financial gains of Wołowski himself ${ }^{17}$. The second seems a little less obvious, but at least just as likely. Throughout his life in exile, Ludwik Wołowski was associated with the Hotel Lambert. He was the secretary of the Literary Society in Paris [Polish Library in Paris: BPP 1361, 1368-91], he supported the Institute of Polish Maidens. In 1861 he entered the Paris Office of Polish Affairs at Czartoryski. During the January Uprising he was a member of the Polish Committee in Paris. And most of all, for many years he was the vice-president of the Council of the Polish National School in Batignolles; As Iwona Pugacewicz writes, the school took advantage of loans granted by Crédit Foncier, and while

${ }^{17}$ Markiewicz examined the legacy of Wołowski. He stated that he had left his only daughter about 1,250,000 francs in stocks, bills, bonds, bank accounts and cash after his death. [Markiewicz P., 1993: Annex, 40]. 
mentioning the name of Wołowski, "all the doors of the most important Parisian institutions were opened" [Pugacewicz I.H., 2017: 126]. These words may be the answer to the question posed earlier: presence on the boards of both banks, close contacts with the most important entrepreneurs and politicians in France, gave him opportunities to act that no other emigrant had. It is no coincidence that in the Polish Committee Wołowski played the role of an intermediary between Poles and French journalists and politicians [Czartoryski W., 1960: 206-322]. Judging by Pugacewicz's words, he was doing it well. However, the price could be, among others silence on banking irregularities.

\section{CONCLUSIONS}

Ludwik Wołowski was therefore not an unambiguous figure. However, he did not differ in this respect from many other figures of the epoch, and even today he seems to be emblematic of the time of the Second Empire in many respects. His approach to the economy largely corresponded to the vision of Napoleon III and his entourage. It was not only about the issue of mortgage law or land loan, but also about the liberal school, which dominated science at that time. Wołowski represented to a large extent a way of thinking similar to those of contemporary French economics, such as Adolphe Blanqui, Frédéric Bastiat, Joseph Garnier, Léon Faucher and Michel Chevalier. They all preached a similar, liberal approach to the free market, freedom of trade. Importantly, their views also reached the circles of power: it was the liberal Chevalier who was, by the anointing of Napoleon III, the main negotiator of a trade treaty with Great Britain in 1860. Chevalier was also one of the emperor's most important economic advisers.

Wołowski's credit concepts fit well with the visions of contemporary banking tycoons such as the Pereire brothers or Benoit Fould (a banker, Achille's brother). The Pereires, in turn, shared the view of banking by Rodrigues, the director and originator of the Mortgage Fund from 1816, and their cousin and close friend at the same time. Rodrigues himself, on the other hand, worked closely with Fould. Wołowski, however, to a greater extent than the others - with the exception of Rodrigues - paid attention to the land mortgage loan. His publications undoubtedly contributed to the increased awareness of the problem of the weakness of agricultural credit. However, his proposed solution, modeled on the Polish one, had 
no chance of being implemented initially for political reasons. He was also not favored by the political instability of the Second Republic, when Wołowski himself became directly involved in parliamentary activities.

Paradoxically, the best conditions for the implementation of his ideas were offered by the Second Empire, a state that legally and systemically deviated from its ideals the most. It was Napoleon III who finally introduced the reform of the mortgage system, which the Pole had been striving for for a long time. It was Napoleon III again who made the first agricultural credit institutions possible.

In this case, however, the wishes of Wołowski and the imperial ministers headed by Persigny did not come true, or at least not entirely - the bank invested mainly outside agriculture. Thus, while in the matter of the mortgage reform, the Pole could speak of some personal success after 1855 , in the matter of the land loan, he undoubtedly failed.

By co-creating Crédit Foncier, however, he contributed to a fundamental change that took place in French and European finance during this period. The Polish economist played an important, though clearly limited, role in it. In the Second Empire, Wołowski was one of the smaller links of an extensive network of connections (friendly or hostile) which was the basis of the banking revolution that took place in the 1850s and 1860s in France, the symbol of which was Pereire and the name of the bank established by the brothers Crédit Mobilier (created as Crédit Foncier in 1852). These new types of banks - one should add Crédit Industriel et Commercial, the first French commercial bank - created a new type of banking for the needs of a developing country, "industrialized credit", as Nicolas Stoskopf, an eminent expert on the French economy of that period, writes.

In these new type of banks, the world of finance regularly met and mingled with the world of politics. In the authoritarian Empire, devoid of almost any social or political control, this had to lead in many cases to corruption and abuse, of which the Haussmann vouchers were an obvious example. However, this does not change the fact that the entire system turned out to be extremely durable, and some names such as Crédit Industriel et Commercial, Crédit Lyonnais (established in 1863), Société Générale (1864) have become a permanent part of the European banking landscape.

And of course Crédit Foncier. Due to the disastrous Franco-Prussian war of 1870-1871 and the fall of the Second Empire, the storm after Ferry's publication was quiet. Later, when republican France had to pay off a gigantic war contribution, no one was going to weaken such an important 
financial instrument. In 1877, Frémy left, in 1878 Soubeyran, the bank was headed by more cautious Republicans. Wołowski's work survived two world wars, the Great Depression, the Cold War and the rule of the coalition of socialists and communists in the 1980s. Crédit Foncier closed its doors in 2019.

\section{REFERENCES}

\section{Printed sources}

Alonier E., Décembre J. (1868), Le coup d'État du 2 décembre 1851 : historique des événements qui ont précédé le coup d'État, physionomie de Paris, arrestations et barricades, types et portraits des principaux personnages, faits qui ont suivi la chute de la république, pièces et documents officiels, Décembre-Alonnier Libraire-Éditeur, Paris.

Czartoryski W. (1960), Pamiętnik 1860-1864, Państwowe Wydawnictwo Naukowe, Warszawa.

Daumier, H. (1808-1879), (n.d.), Album comique, par Daumier. Vol. 2. Journal amusant (Paris). http://gallica.bnf.fr/ark:/12148/bpt6k377110v, accessed 21.01.2021.

Josseau J.B. (1872), Traité du crédit Foncier suivi d'un traité $d u$ crédit agricole et du crédit Foncier colonial, contenant l'explication théorique et pratique de la législation spéciale, Cosse, Marchale et Billard Imprimeurs-Éditeurs, Paris 1872.

Journées illustrées de la Révolution de 1848 (1948), Aux Bureaoux de L'Illustration, rue de Richelieu, 60, Paris.

Kodeks Napoleona z przypisami. Xiag trzy (1810), Drukarnia XX. Piarów, Warszawa.

Moniteur Universel (1848), Journal Officiel de la République Française.

Moniteur Universel (1849), Journal Officiel de la République Française.

Troplong R.T. (1856), Privilèges et hypothèques, commentaire de la loi du 23 mars 1855 sur la transcription en matière hypothécaire, Charles Hingray Libraire-Éditeur, Paris.

Wolowski L. (1832), Thèse pour la licence, Rignoux.

Wolowski L. (dir.), (1835), Revue de Législation et de Jurisprudence, I, 48.

Wolowski L. (1839), De la mobilisation du crédit Foncier, Revue de Législation et de Jurisprudence, X, 242-249.

Wolowski L. (1844), Réforme hypothécaire : organisation du crédit Foncier, Guillaumin, Paris.

Wolowski L. (1847), Discours prononce au 17 anniversaire de la Revolution polonaise (29 novembre 1847), Paris.

Wolowski L. (1849), Réforme hypothécaire, Revue de Législation et de Jurisprudence, II.

Wolowski L. (1850a), Rapport fait au Conseil Général de l'Agriculture, du Commerce et des Manufactures par M. Wolowski, Représentant du peuple, membre du Conseil général, Au nom de la Commission chargée de la question relative au crédit Foncier, Revue de Législation et de Jurisprudence, II.

Wolowski L. (1850b), Rapport fait par M. Wolowski, Représentant du Peuple, membre du Conseil Général, au nom de la Commission chargée de la question relative au crédit Foncier, Paris.

Wolowski L. (1870), Quelques observations présentées à la Commission du Corps législatif chargée de l'examen du traité entre la Ville de Paris et le Crédit Foncier, Imprimerie de P. Dupont, Paris.

Bibliothèque Nationale de France (2021), https:/ / gallica.bnf.fr, accessed 21.01.2021.

Polona (2021), https:// polona.pl, accessed 21.01.2021. 


\section{Literature}

Allinne J-P. (1984), Banquiers et bâtisseurs : un siècle de Crédit Foncier, 1852-1940, Editions du CNRS, Paris.

Bajon K. (2011), Polski bankier i francuska rewolucja bankowa, www.newsweek.pl 05. 02. 2011, https:/ / www.newsweek.pl/polski-bankier-i-francuska-rewolucja-bankowa/zy 0xxps, accessed 21.01.2021.

Barjot D. (1995), Histoire économique de la France au XIX siècle, Nathan, Paris.

Barjot D., Chalinne J.-P., Encrevé A. (1995) La France au XIXe siècle 1814-1914, Presses Universitaires de France, Paris.

Blajer P. (2016), Z dziejów francuskiego modelu «la publicité foncière», Zeszyty Prawnicze, XVI, 1, 89-133.

Borejsza J. (1966), Emigracja polska po powstaniu styczniowym, Państwowe Wydawnictwo Naukowe, Warszawa.

Bourloton B., Cougny G., Robert A. (1891), Dictionnaire des parlementaires français... : depuis le 1er mai 1789 jusqu'au 1er mai 1889.... t. III, Bourloton Éditeur, Paris.

Chaudun N. (2009), Haussmann Georges-Eugène, préfet - baron de la Seine, Actes Sud, Paris.

Gałkowski A. (2004), Polski patriota, obywatel Francji i Europy, czyli krótka opowieść o Ludwiku Wołowskim [in:] Judycka A., Judycki Z. (eds.), Polacy we Francji : historia i wspótczesność : materiaty VIII Międzynarodowego Sympozjum Biografistyki Polonijnej: Stella-Palge, Vaudricourt, 2-3 października 2004, Oficyna Wydawnicza CAN, Warszawa, 37-44.

Gerber R. (1977), Studenci Uniwersytetu Warszawskiego. Stownik biograficzny, Ossolineum, Wrocław, Warszawa, Kraków, Gdańsk.

Gille B. (1970), La Banque de France au XIX siècle. Recherches historiques, Librairie Droz, Genève.

Girard L. (1981), Nouvelle histoire de Paris. La Deuxième République et le Second Empire 18481870, Hachette, Paris.

Górski J., Sierpiński W. (1979), Historia powszechnej myśli ekonomicznej (1870-1950), Państwowe Wydawnictwo Naukowe, Warszawa.

Grzybek D. (2012), Polityczne konsekwencje idei ekonomicznych w myśli polskiej 1869-1939, Księgarnia Akademicka, Kraków.

Gueslin A. (1978), Les Origines du Crédit Agricole (1840-1914), Université de Nancy II, Nancy.

Guzicki L., Żurawicki S. (1969), Historia polskiej myśli społeczno-ekonomicznej do roku 1914, Państwowe Wydawnictwo Ekonomiczne, Warszawa.

Heugas-Darraspen H., Raimbault A. (1994), Crédit Foncier de France. Itinéraire d'une institution, Éditions du Regard, Paris.

Kowalik T. (1992), Historia ekonomii w Polsce 1864-1950, Zakład Narodowy im. Ossolińskich, Wrocław, Warszawa, Kraków.

Levasseur É. (1877), La vie et les travaux de Wolowski, Imprimerie Viébille et Capiomont, Paris.

Lityńska A. (1994), Polska szkoła historyczna w ekonomii, Wydawnictwo Oddziału Polskiej Akademii Nauk, Kraków.

Łyczywek R. (1983), Stownik biograficzny adwokatów polskich S-Ż, t. I, Wydawnictwo Prawnicze, Warszawa.

Marchand B. (2011), Le financement des travaux d'Haussmann : un exemple pour les pays émergents ?, https://halshs.archives-ouvertes.fr/halshs-00583457/document, accessed 28.02.2021.

Markiewicz P. (1993) Louis Wolowski, un intellectuel et un représentant du libéralisme en France au milieu du 19 siècle, Universite Paris X Nanterre, U-E-R d'Histoire, Doctorat nouveau régi- 
me, présenté et soutenu publiquement par Patrice Markiewicz, sous la direction de Monsieur Philippe Vigier [typescript].

Polska klasyczna myśl ekonomiczna na tle angielskiej i francuskiej, (2009), Zagóra-Jonszta U. (ed.), Wydawnictwo Akademii Ekonomicznej im. Karola Adamieckiego, Katowice.

Pugacewicz I.H. (2017), Batignolles 1842-1874. Edukacja Wielkiej Emigracji, Oficyna Wydawnicza ASPRA-JR, Warszawa.

Roulliet A. (1880), Wolowski. Sa vie et ses travaux, Guillaumin et Cie Editeurs, Paris.

Skałkowski T. (1892), Towarzystwa kredytowe ziemskie w ziemiach polskich. Szkic historyczny, Drukarnia Związkowa, Lwów.

Stankiewicz W. (2007), Historia myśli ekonomicznej, Polskie Wydawnictwo Ekonomiczne, Warszawa.

Vigier Ph. (1995) Le coup d'Etat de Louis-Napoléon Bonaparte, https://1851.fr/auteurs/vigier/, accessed 16.02.2021.

Wachowicz B. (1983), Towarzystwo Kredytowe Ziemskie w Królestwie Polskim w okresie powstania listopadowego, Annales Universitatis Mariae Curie-Skłodowska, 37, 61-82.

Zdrada J. (1969), Zmierzch Czartoryskich, Państwowe Wydawnictwo Naukowe, Warszawa.

The text written as part of the project of the National Science Center (Narodowe Centrum Nauki): „Życie i działalność Ludwika Wołowskiego (1810-1876)" [The life and activity of Ludwik Wołowski (1810-1876)], agreement no: UMO-2018/29/B/HS3/00523.

Rafał Dobek: born in 1973, a graduate of European Studies at the Adam Mickiewicz University in Poznań, professor at the Adam Mickiewicz University in the Faculty of History. He works on the history of $19^{\text {th }}$-century France, the history of Polish emigration to France in the $19^{\text {th }}$ century, the history of Greater Poland between 1815 and 1914, and the history of political ideas in the $19^{\text {th }}$ century. He is the author of, among others, the monographs Raymond Aron - dialog z historia i polityka, Poznan 2005; Pierre-Joseph Proudhon, Poznań 2013; Paryż, 1871, Poznań 2013. 